\title{
Calpain inhibition impairs glycogen syntheses in HepG2 hepatoma cells without altering insulin signaling
}

\author{
Markus Meier, Harald H Klein ${ }^{\mathbf{1}}$, Jan Kramer, Maren Drenckhan and Morten Schütt ${ }^{\mathbf{2}}$ \\ Department of Internal Medicine I, University of Lübeck, Ratzeburger Allee 160, D- 23538 Lübeck, Germany \\ ${ }^{1}$ Department of Internal Medicine, University Clinic Bergmannsheil, Ruhr-University Bochum, Bochum, Germany \\ ${ }^{2}$ Curschmann-Klinik, Timmendorfer Strand, Germany \\ (Requests for offprints should be addressed to M Meier; Email: markus.meier@uni-luebeck.de)
}

\begin{abstract}
Calpains are a family of non-lysosomal cytoplasmatic cysteine proteases. Since calpain 10 (CAPN10), a member of the calpain family of proteases, has been found to represent a putative diabetes susceptibility gene, it was argued that calpains may be involved in the development of type 2 diabetes. The functional role of calpains in insulin signaling and/or insulin action is, however, not clear. We investigated the effects of the calpains 1 and 2 inhibitor PD151746 on insulin signaling and insulin action in human hepatoma G2 cells (HepG2). HepG2 cells were incubated without (-PD) or with (+PD) $5 \cdot 33 \mu \mathrm{mol} / 1$ PD151746 for different times and then stimulated with $100 \mathrm{nmol} / 1$ insulin for $0\left(t_{0}\right), 5\left(t_{5}\right), 15\left(t_{15}\right), 30\left(t_{30}\right), 45\left(t_{45}\right)$, and $60\left(t_{60}\right) \mathrm{min}$. After solubilization of the cells, insulin receptor kinase activity, tyrosine phosphorylation of insulin receptor substrate-1 (IRS-1), IRS-1-associated phosphatidylinositol-3 kinase (PI3-kinase), PI3-kinase activity, $\mathrm{Thr}^{308}$ phosphorlyation of Akt, amount of protein tyrosine phosphatase- $\varepsilon$ (PTPE), and glycogen synthase activity were determined. Incubation with
\end{abstract}

PD151746 resulted in a significant reduction of insulinstimulated glycogen synthesis compared with cells not preincubated with the calpain inhibitor ( $-\mathrm{PD}: t_{0}, 4 \cdot 90 \pm 1 \cdot 20 \% ; t_{5}$, $5 \cdot 90 \pm 1 \cdot 02 \% ; t_{15}, 5 \cdot 29 \pm 0 \cdot 95 \% ; t_{30}, 5 \cdot 60 \pm 1 \cdot 10 \% ; t_{45}, 5 \cdot 52 \pm$ $0 \cdot 90 \% ; t_{60}, 5 \cdot 67 \pm 0 \cdot 97 \%$; PD: $t_{0}, 4 \cdot 56 \pm 1 \cdot 10 \% ; t_{5}, 6 \cdot 16 \pm$ $1 \cdot 05 \% ; t_{15}, 7 \cdot 52 \pm 1 \cdot 09 \% ; t_{30}, 7 \cdot 68 \pm 1 \cdot 10 \% ; t_{45}, 8 \cdot 28 \pm 0 \cdot 89 \%$; $\left.t_{60}, 7 \cdot 69 \pm 0 \cdot 98 \% ; P<0 \cdot 05\right)$. Incubation with PD151746 significantly increased the protein amount of PTPE in the cells after $12 \mathrm{~h}$ (-PD: $t_{1}, 0 \cdot 85 \pm 0 \cdot 18 \mathrm{RU}$ (Relative unit); $t_{8}, 0 \cdot 87 \pm$ $0.18 \mathrm{RU} ; t_{12}, 0.9 \pm 0.13 \mathrm{RU} ;+\mathrm{PD}: t_{1}, 0.92 \pm 0 \cdot 21 \mathrm{RU}$; $\left.t_{8}, 1 \cdot 1 \pm 0 \cdot 15 \mathrm{RU} ; t_{12}, 1 \cdot 34 \pm 0 \cdot 16 \mathrm{RU} ; P<0 \cdot 05\right)$. Calpain inhibition with PD151746 had no effect on the insulin stimulation of the investigated insulin signaling parameters. These results in HepG2 cells suggest that calpains play a role in the hepatic regulation of insulin-stimulated glycogen synthesis independent of the PI3-kinase/Akt signaling pathway.

Journal of Endocrinology (2007) 193, 45-51

\section{Introduction}

Type 2 diabetes mellitus is characterized by peripheral insulin resistance, i.e. the loss of an appropriate response to insulin at normal levels. Since the development of type 2 diabetes has a strong genetic background, genes encoding proteins with effects on insulin signaling and/or insulin action are of special interest in order to understand the underlying molecular mechanism of the insulin resistance and to develop effective treatments. Recent studies have identified a member of the calpain family of proteases, CAPN10, as a diabetes susceptibility gene (Horikawa et al. 2000, Cox et al. 2004). Although variations in the gene that encodes CAPN10 are associated with increased risk for type 2 diabetes in specific populations, the role of calpains in the development of type 2 diabetes is not clear (Baier et al. 2000, Lynn et al. 2002, Malecki et al. 2002).

Calpains or calcium-activated neutral proteases are a family of non-lysosomal cytoplasmatic cysteine proteases that catalyze the endoproteolytic cleavage of specific substrates and thereby regulate pathways which affect intracellular signaling. Fourteen members of the calpain family have been identified so far, some of which are tissue specific whereas others are ubiquitously expressed (Goll et al. 2003). Several data of recent studies suggest that calpains are involved in the regulation of glucose homoeostasis. Yang et al. (2001) have shown that a specific single-nucleotide polymorphism43 (SNP-43) within the CAPN10 gene was associated with elevated fasting blood glucose and insulin levels and decreased CAPN10 mRNA levels in the skeletal muscle of non-diabetic Pima Indians. Furthermore, in vitro studies on effects of CAPN1 ( $\mu$-calpain) and/or CAPN2 (m-calpain) inhibitors revealed that inhibition of calpain activity results in increased insulin secretion in isolated rat pancreatic islets (Sreenan et al. 2001, Parnaud et al. 2005) and a significantly decreased insulin-stimulated glucose uptake in isolated rat muscle strips and adipocytes (Sreenan et al. 2001) as well as in 3T3-L1 adipocytes (Paul et al. 2003). These data suggest a potential 
link between calpain activity and the insulin signaling pathway resulting in insulin action.

Cellular insulin signaling is initiated by binding to its specific cell surface receptor, followed by rapid phosphorylation of tyrosine residues on the receptor $\beta$-subunit. This results in phosphorylation of several intracellular substrates including insulin receptor substrates (IRSs) 1-4. Binding of tyrosine-phosphorylated IRSs to the $85 \mathrm{kD}$ regulatory subunit of the lipid kinase phosphatidylinositol-3 kinase (PI3-kinase) then results in an activation of this enzyme. PI3-kinase is necessary for the insulin-mediated stimulation of the serine/threonine kinase Akt which is activated by phosphorylation at the $\mathrm{Thr}^{308}$ and $\mathrm{Ser}^{473}$ residues (Pirola et al. 2004). Upon activation, Akt phosphorylates and inactivates glycogen synthase kinase-3 (GSK-3), resulting in the dephosphorylation and activation of glycogen synthase (GS; Patel et al. 2004).

In order to assess the role of calpain activity in insulin signaling and insulin action in a human cell model, we investigated whether inhibition of CAPN1 and CAPN2 by PD151746 alters insulin-stimulated glycogen synthesis and/or insulin signal transduction in hepatoma G2 (HepG2) cells.

\section{Materials and Methods}

Fetal calf serum (FCS) was purchased from Biochrom (Berlin, Germany), Leibovitz-L15 medium from Gibco. Porcine monocomponent insulin was from Novo Biolabs (Bagsvaerd, Denmark), $\left[{ }^{125} \mathrm{I}-\mathrm{Tyr}-\mathrm{A}^{14}\right]$-monoiodoinsulin from Amersham, ${ }^{32} \mathrm{P}$-ATP, and ${ }^{14} \mathrm{C}$-glycogen uridine diphosphate glucose (UDPG) were from NEN Life Science Products (Boston, NE, USA). Goat anti-mouse IgG was obtained from Dianova (Hamburg, Germany) and peroxidase-labeled antibodies from Dako (Glostrup, Denmark). Rabbit polyclonal antibodies against IRS-1, PI3-kinase $85000 M_{\mathrm{r}}$ regulatory subunit and recombinant IRS-1 were from Upstate Biotechnology (Lake Placid, NY, USA). Antibody against $\mathrm{Thr}^{308}$ phosphorylation of Akt was obtained from Cell Signaling (Beverly, MA, USA). Rabbit polyclonal antibody against the cytoplasmatic domain of protein tyrosine phosphatase- $\varepsilon$ (PTPE) was from Abcam, Inc. (Cambridge, MA, USA). The calpain inhibitor PD151746 as well as m-calpain were obtained from Calbiochem (San Diego, CA, USA). Other chemicals were from Sigma or Roche.

\section{Preparation of PD151746 stock solution and cell incubation}

We used HepG2 cells, since these cells represent an established human cell model for the study of cellular insulin signaling and insulin effects. Furthermore, they allow an investigation of long-term effects (Hofmann et al. 1980, Qiu et al. 2004). To prepare the PD151746 stock solution, 1.0 mg PD151746 powder was dissolved in $1 \mathrm{ml}$ dimethylsulfoxide (DMSO)/ methanol. This was added to Leibovitz-15 medium and the $\mathrm{pH}$ adjusted to $7 \cdot 4$ with $\mathrm{NaHCO}_{3}$ (final volume $5 \mathrm{ml}$ ). Stock solution for controls was similarly prepared except that the DMSO/methanol did not contain PD151746. HepG2 cells that had grown to near confluency (Leibovitz-15 medium supplemented with $10 \%$ FCS, $5 \mathrm{mmol} / \mathrm{l}$ glucose, $2 \cdot 5 \mu \mathrm{l} / \mathrm{ml}$ transferrin, $60 \mu \mathrm{g} / \mathrm{ml}$ fetuin, and $20 \mu \mathrm{g} / \mathrm{ml}$ gentamicin at $37^{\circ} \mathrm{C}$ under an atmosphere of $95 \%$ air and $5 \% \mathrm{CO}_{2}$ ) were starved for $24 \mathrm{~h}$ in Leibovitz-15 medium that contained the same supplements as described above but only 1\% FCS (Hofmann et al. 1980). Then, the medium was replaced by $19.9 \mathrm{ml}$ incubation buffer $(20 \mathrm{mmol} / \mathrm{l}$ HEPES (hydroxyethylpiperazine-ethansulfonic acid), $130 \mathrm{mmol} / 1 \mathrm{NaCl}, 4 \cdot 8 \mathrm{mmol} / 1$ $\mathrm{KCl}, 1.3 \mathrm{mmol} / 1 \quad \mathrm{KH}_{2} \mathrm{PO}_{4}, 1 \mathrm{~g} / \mathrm{l}$ D-glucose, $1.3 \mathrm{mmol} / 1$ $\mathrm{MgSO}_{4}, 1 \cdot 2 \mathrm{mmol} / 1 \mathrm{CaCl}_{2}, 2 \% \mathrm{BSA}(\mathrm{pH} 7 \cdot 4)$ ) to which $100 \mu \mathrm{l}$ stock solution without or with PD151746 (final concentration $5.33 \mu \mathrm{mol} / \mathrm{l}$ ) had been added and cells were incubated for $1 \mathrm{~h}$. We chose $1 \mathrm{~h}$ of incubation without or with $5 \cdot 33 \mu \mathrm{mol} / 1 \mathrm{PD} 151746$ because preceding experiments had shown that PD151746 had similar effects on IRS-1 phosphorylation, IRS-1 amount, $\mathrm{Thr}^{308}$ phosphorylation of Akt or on Akt amount after $5 \mathrm{~min}, 20 \mathrm{~min}, 4 \mathrm{~h}$, or $12 \mathrm{~h}$ and that $0 \cdot 053,0 \cdot 53$, or $53 \cdot 5 \mu \mathrm{mol} / 1$ PD151746 were similarly potent (data not shown). To confirm adequate inhibitor function, casein zymography electrophoresis was performed as described (Raser et al. 1995; Fig. 1).

\section{Cell number and viability}

At the end of the incubations, cells were counted in a Neubauer chamber and viability was tested with Trypan blue exclusion.

\section{Insulin stimulation and solubilization of cells}

Cells were preincubated as described earlier. Then, incubation buffer with 0 or $100 \mathrm{nmol} / 1$ insulin was added and cells incubated for different times at $37^{\circ} \mathrm{C}$. Subsequently, the buffer was removed and the dishes with the cells rapidly frozen in liquid nitrogen. The thin ice layer that contained the cells was scraped off from the dishes at $-20{ }^{\circ} \mathrm{C}$ and homogenized

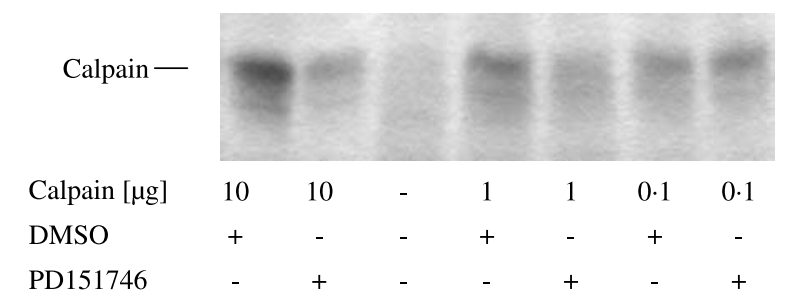

Figure 1 In vitro effects of PD151746 in casein zymographies. To confirm adequate inhibitor function, various amounts of calpain $(0 \cdot 1-10 \mu \mathrm{g}$, specific activity $>1000$ units/mg protein) were incubated with or without DMSO (1:100) and with or without the calpain inhibitor PD151746 (5.33 $\mu \mathrm{mol} / \mathrm{l})$ for $5 \mathrm{~min}$. Samples were then electrophoresed into a casein gel $(0 \cdot 2 \%)$ and subsequently incubated in a proteolysis buffer for $60 \mathrm{~min}$. The gel was then incubated overnight at room temperature and finally stained with Coomassie blue. Shown is a casein zymogram representative of two separate experiments. 
with a motor-driven Potter homogenizer in a solution that contained 2\% Triton X-100, $5 \mathrm{mmol} / 1$ phenylmethylsulfonylfluoride, $800 \mathrm{U} / \mathrm{ml}$ trypsin inhibitor aprotinin, $8 \mathrm{mmol} / 1$ EDTA, $30 \mathrm{mmol} / 1$ benzamidine, $2 \cdot 5 \mu \mathrm{g} / \mathrm{ml}$ pepstatin, $2.5 \mu \mathrm{g} / \mathrm{ml}$ leupeptin, $160 \mathrm{mmol} / 1 \mathrm{NaF}, 10 \mathrm{mmol} / 1$ sodium pyrophosphate, $0.2 \mathrm{mmol} / 1$ sodium vanadate, $2 \mathrm{mmol} / 1$ dichloroacetic acid, and $20 \mathrm{mmol} / 1$ HEPES (pH 7•4; final concentrations, Schütt et al. 2000). Samples were then centrifuged at $10^{5} \mathrm{~g}\left(4^{\circ} \mathrm{C}\right)$ to remove insoluble material. Protein concentration was measured using the BioRad protein dye-binding assay.

\section{Insulin receptor kinase and binding capacities}

These were measured as previously described (Klein et al. 1993). Briefly, $30 \mu \mathrm{l}$ cell sample lysates were added to microwells coated with anti-insulin receptor antibody for $16 \mathrm{~h}$ at $4{ }^{\circ} \mathrm{C}$. The wells were washed and receptor-mediated ${ }^{32} \mathrm{P}$ incorporation into recombinant IRS-1 (17 nmol/l) measured at $120 \mathrm{nmol} / 1{ }^{32} \mathrm{P}$-ATP. [ $\left.{ }^{125} \mathrm{I}-\mathrm{Tyr}-\mathrm{A}^{14}\right]$-monoiodoinsulin binding to immobilized insulin receptors was also measured in the wells (Klein et al. 1993). Insulin-binding activity (BA) was defined as the amount of specifically bound insulin at a concentration of $8.7 \mathrm{nmol} / 1$ and analyzed as described earlier (Klein et al. 1995). Finally, IR kinase activity was expressed as attomoles phosphate incorporated into IRS-1 per minute per femtomole of insulin binding.

\section{Immunoblots}

Solubilized cells $(300 \mu \mathrm{g}$ protein) were incubated overnight with $1 \mu \mathrm{g}$ anti-IRS-1 antibody and then added to $30 \mu \mathrm{l}$ packed agarose beads cross-linked with protein G. Bound proteins were detached with Laemmli buffer, boiled, and subjected to SDS-PAGE. For the determination of $\mathrm{Thr}^{308}$-phosphorylated Akt and PTPE, cell lysates $(100 \mu \mathrm{g}$ protein) were directly subjected to SDS-PAGE (7.5\%). Proteins were then transferred to nitrocellulose membranes. Membranes were blocked in BSA (3\% in Tris (hydroxymethyl) aminomethane buffered saline (TBS-T)) and incubated with the specific antibodies for $2 \mathrm{~h}$. Bound antibodies were detected by peroxidase-labeled antibodies and chemiluminescence.

\section{IRS-1-associated PI3-kinase activity}

PI3-kinase activity was determined as described (Kolter et al. 1997). Briefly, $60 \mu \mathrm{l}$ reaction mixture containing $0 \cdot 2 \mathrm{mg} / \mathrm{ml}$ PI, $20 \mathrm{mM}$ HEPES (pH 7.2), $0.4 \mathrm{mM}$ EGTA, $0.4 \mathrm{mM}$ $\mathrm{Na}_{2} \mathrm{HPO}_{4}$, and $10 \mathrm{mM} \mathrm{MgCl} 2$ with or without wortmannin $(1 \mu \mathrm{M})$ were added to the immunoprecipitates. The kinase buffer was incubated with the immunoprecipitates for $5 \mathrm{~min}$ at room temperature, and the reaction was started by the addition of $\left[\gamma^{-32} \mathrm{P}\right]$ ATP $(40 \mu \mathrm{M}$ and $0 \cdot 2 \mathrm{Ci} / \mu \mathrm{l})$. After $20 \mathrm{~min}$, the reaction was stopped by the addition of $40 \mu \mathrm{l}$ of $4 \mathrm{~N} \mathrm{HCl}$ and $190 \mu \mathrm{l}$ chloroform-methanol (1/1). The organic phase was extracted and spotted on a silica gel thin-layer chromatography plate (Merck) and was developed in chloroform-methanol-15\% $\mathrm{NH}_{4} \mathrm{OH}$-water (43:28:5:7, v/v). Plates were dried and radioactivity incorporated into PI quantified by a phosphoimager.

\section{Glycogen synthesis}

HepG2 cells were grown and stimulated without or with $100 \mathrm{nmol} / 1$ insulin as described earlier. Subsequently, cells were solubilized and GS activity was determined as previously described (Vaag et al. 1992). Briefly, GS activity was assayed in the presence of a near physiological concentration of glucose-6phosphate (G6P, $0 \cdot 1 \mathrm{mmol} / \mathrm{l})$ and in the presence of $10 \mathrm{mmol} / \mathrm{l}$ G6P to determine maximal enzyme activity. The substrate concentration of UDPG was $7 \mathrm{mmol} / 1$ and GS activity was expressed as nmol of UDPG incorporated into glycogen per minute. Fractional velocities (FVs) were calculated as the ratio between GS activities assayed at $0 \cdot 1$ and $10 \mathrm{mmol} / 1(\mathrm{FV} 0 \cdot 1)$.

\section{Data analysis}

In every western blot, all bands were compared (three to four time points $-/+$ PD151746) by scanning densitometry. Relative units represent the ratio between the intensity of the single bands and the mean intensity of all bands in the same blot. Differences were tested by $t$-statistics for paired data (SigmaStat 3.0, SPSS, Inc., Chicago, IL, USA). $P \leq 0 \cdot 05$ was considered significant.

\section{Results}

\section{Cell number and viability}

PD151746 had no effect on cell number $\left(1 \cdot 22 \times 10^{5} \pm 0 \cdot 19\right.$ and $1.25 \times 10^{5} \pm 0 \cdot 13$ cells/dish treated with or without PD151746 respectively) or cell viability $(8 \cdot 5 \pm 0 \cdot 16$ and $9 \cdot 1 \pm$ $0 \cdot 12 \%$ Trypan blue-positive cells/dish respectively). Moreover, there were no detectable morphological changes between cells treated with or without PD151746.

\section{In vitro calpain activity}

Incubation of 1 and $10 \mu \mathrm{g}$ calpain with PD151746 for $5 \mathrm{~min}$ resulted in a significant irreversible reduction of calpain activity in casein zymographies of at least $80 \%$ confirming adequate inhibitor function (Fig. 1).

Insulin receptor kinase activity, IRS-1 phosphorylation, association of PI3-kinase with IRS-1, PI3-kinase activity, and $\mathrm{Thr}^{308}$ phosphorylation of $\mathrm{Akt}$

In cells not preincubated with PD151746 insulin rapidly increased IRS-1 phosphorylation, association of PI3-kinase with IRS-1, IRS-1-associated PI3-kinase activity, and $\mathrm{Thr}^{308}$ phosphorylation of Akt (Figs 2-4). In cells preincubated with 


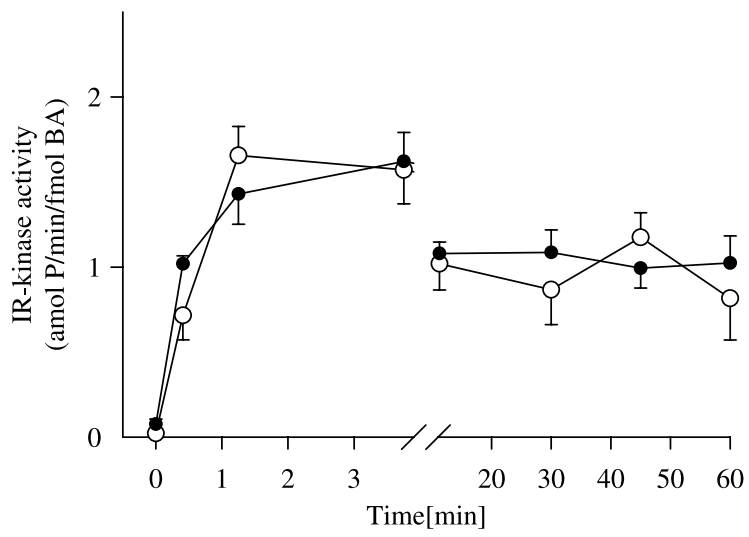

Figure 2 Effects of PD151746 on insulin receptor kinase (IR kinase) activity. HepG2 cells were incubated without $(O)$ or with $5 \cdot 33 \mu \mathrm{mol} / \mathrm{l}$ PD151746 for $1 \mathrm{~h}$ and then stimulated with $100 \mathrm{nmol} / \mathrm{l}$ insulin for the indicated times. Cells were solubilized and $30 \mu \mathrm{l}$ lysates $(3.5 \mathrm{mg} / \mathrm{ml})$ were added to microwells coated with anti-IR antibody at $4{ }^{\circ} \mathrm{C}$. After overnight, incubation wells were washed, and the kinase activity of immobilized IR was measured in the presence of $0 \cdot 3 \mu \mathrm{mol} / /$ ATP containing $3 \mu \mathrm{Ci} /$ well $\left[\gamma_{-}{ }^{32} \mathrm{P}\right]$-ATP and $2 \cdot 4 \mu \mathrm{g} / \mathrm{ml}$ recombinant IRS-1. The wells were washed again and insulin-binding activity (BA) was analyzed. IR kinase activity was expressed as attomoles phosphate incorporated into IRS-1 per minute per femtomole of insulin binding. Shown are means \pm S.E.M. $(n=5)$.

the calpain inhibitor PD151746, similar activation characteristics of the signal parameters were noticed and no statistical differences were detected between cells treated with or without the inhibitor (Figs 2-4). PD151746 had no effects on the amounts of IRS-1 or Akt (data not shown).

\section{Glycogen synthesis}

Insulin stimulation increased GS activity in cells not preincubated with PD151746 by $25-45 \%$. The greatest effects were observed after $45 \mathrm{~min}$. Preincubation with PD151746 resulted in a significant reduction of insulinstimulated GS activity after $15,30,45$, and $60 \mathrm{~min}$ by $30-40 \%$ respectively (Fig. 5).

\section{Protein expression of PTPE}

In cells preincubated for $1 \mathrm{~h}$ with the calpain inhibitor PD151746, insulin stimulation did not alter the amount of the PTP $\varepsilon$ protein (Fig. 6A). However, the incubation of HepG2 cells with PD151746 for 8 or $12 \mathrm{~h}$ resulted in an increase of the PTP $\varepsilon$ protein expression by $20-30 \%$ respectively. This alteration in the amount of the PTP $\varepsilon$ protein was significant after an incubation period of $12 \mathrm{~h}(P=0 \cdot 035$; Fig. 6B).

\section{Discussion}

In this study, we describe that the incubation of HepG2 cells with the calpain inhibitor PD151746 over a period of

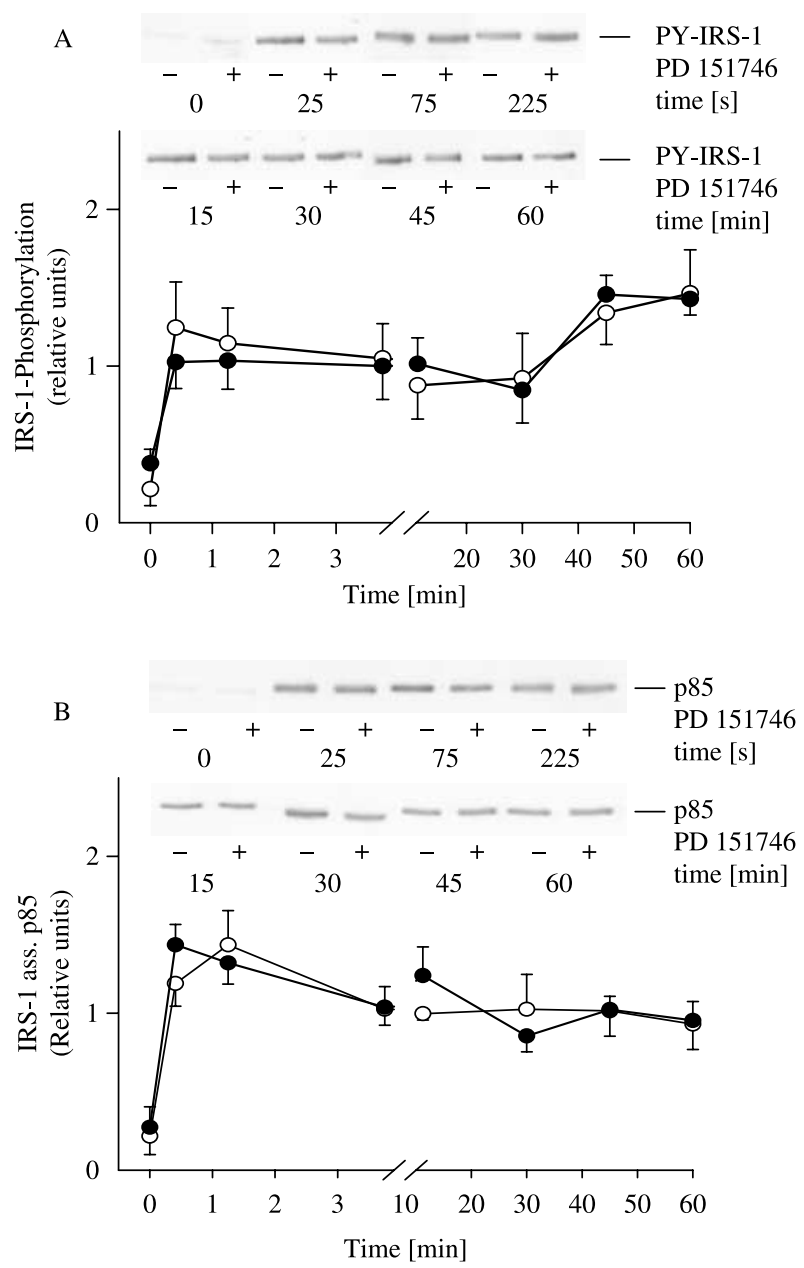

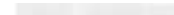
$\mathrm{C} \quad-\quad+\ldots+-+\ldots+\mathrm{PD}^{2} \mathrm{~A} 1746$ $0^{+}-{ }_{25}^{+}{ }_{75}^{+}{ }_{225}^{+}$time [s]

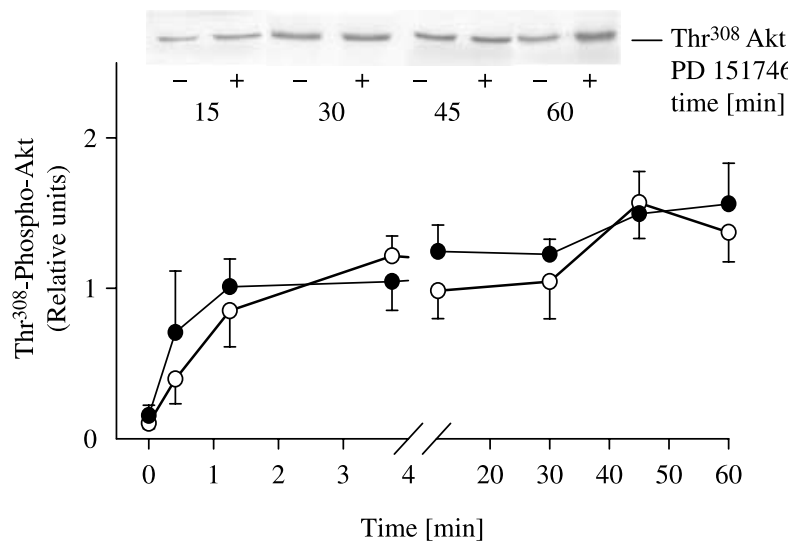

www.endocrinology-journals.org 
15-60 min resulted in an approximately 40\% reduction of insulin-stimulated GS activity respectively. A similar result with a highly reduced insulin-stimulated glycogen synthesis rate after CAPN2 inhibition was also found in a recent study by Sreenan et al. (2001) in rat muscle strips.

The effect of calpain inhibition with PD151746 on insulinstimulated GS activity in HepG2 cells was not associated with alterations in the insulin stimulation of the insulin receptor kinase activity, tyrosine phosphorylation of IRS-1, IRS-1associated PI3-kinase, PI3-kinase activity, or $\mathrm{Thr}^{308}$ phosphorlyation of Akt. These data suggest that the PD151746 effect was caused by alterations at non-studied locations, e.g., downstream signaling elements (Pirola et al. 2004) or the final effector system itself (Patel et al. 2004). A similar result with a decreased insulin effect on glucose homoeostasis independent of the PI3/Akt-kinase pathway was found in a clamp study on insulin-resistant subjects with type 2 diabetes and first-degree relatives of type 2 diabetic patients. Although the glucose disposal was reduced in the diabetic subjects and relatives, no alterations in the insulin-stimulated PI3-kinase activation and $\mathrm{Thr}^{308}$ Akt phosphorylation were found in muscle biopsies obtained at similar steady-state clamp insulin concentrations (Meyer et al. 2002). Another recent study investigated the effect of the insulin signaling-independent muscle contraction-stimulated glucose transport in transgenic mice that overexpress the calpain inhibitor calpastatin. Despite a threeto fourfold increase in glucose transporter-4 protein, calcium calmodulin kinase II and AMP kinase in their skeletal muscles, contraction-stimulated glucose transporter-4 translocation, and glucose transport were not increased above wild type values (Otani et al. 2006). These findings also suggest that the inhibition of calpain results in alterations of a step downstream of the insulin signaling pathways and/or at the level of the final effector system itself.

A potential candidate for such an effect is the PTPE that is known to affect the hepatic glycogen synthesis. Recent studies in primary rat hepatocytes revealed that the expression of PTPE inhibited insulin signaling and GSK-3 $\beta$ mediated hepatic glycogen synthesis (Nakagawa et al. 2005). Moreover, cytosolic PTPE does not inhibit insulin receptor signaling but dephosphorylates several other signaling molecules (Andersen et al. 2001). Since PTPE is also cleaved by calpains (Gil-Henn et al. 2001), inhibition of calpain activity might result in an

Figure 3 Effects of PD151746 on IRS-1 phosphorylation (A), association of p85 with IRS-1 (B) and Thr ${ }^{308}$ phosphorylation of Akt (C). Cells were incubated without $(O)$ or with $(\mathbf{O}) 5 \cdot 33 \mu \mathrm{mol} / \mathrm{I}$ PD151746 for $1 \mathrm{~h}$ and then stimulated with $100 \mathrm{nmol} / \mathrm{l}$ insulin for the indicated times. They were then solubilized and IRS-1 immunoimmobilized with anti-IRS-1 1 antibody bound to protein G agarose beads. The beads were washed, bound proteins detached with Laemmli buffer, and immunoblots performed as described in Materials and Methods. Thr ${ }^{308}$-phosphorylated Akt in cell lysates was measured by immunoblot with specific anti-phospho-Akt antibody. Relative units (RUs) were calculated as described. Shown are means \pm S.E.M. $(n=5)$. Insets show representative blots at the respective time points.

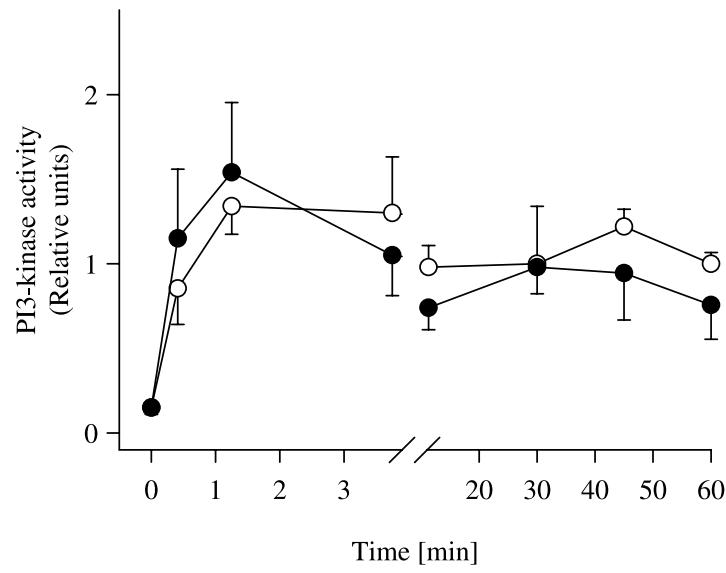

Figure 4 Effects of PD151746 on PI3-kinase activity. Cells were incubated without $(O)$ or with $(\mathbf{O}) 5 \cdot 33 \mu \mathrm{mol} / \mathrm{l}$ PD151746 for $1 \mathrm{~h}$ and then stimulated with $100 \mathrm{nmol} / \mathrm{l}$ insulin for the indicated times. They were then solubilized and IRS- 1 was immunoimmobilized as described in Materials and Methods. Subsequently, $60 \mu \mathrm{l}$ reaction buffer containing PI were added to the immunoprecipitates and the reaction was started by the addition of $\left[\gamma-{ }^{32} \mathrm{P}\right]$ ATP. After $20 \mathrm{~min}$, reaction was stopped by the addition of $40 \mu \mathrm{l} \mathrm{HCl}(4 \mathrm{~mol} / \mathrm{l})$ and $190 \mu \mathrm{l}$ chloroform-methanol. The organic phase was extracted and spotted on a chromatography plate. Plates were developed in chloroformmethanol and radioactivity incorporated into phosphatidylinositol quantified by phosphoimaging. Shown are means \pm S.E.M. $(n=6)$.

altered PTPE protein amount and/or an increased phosphatase activity, and, thus, might reduce GS activity without altering insulin signaling. Our result, that the PTPE protein amount was not altered by the calpain inhibitor after 30 and $60 \mathrm{~min}$, does not support a role of PTPE as a mechanism of a

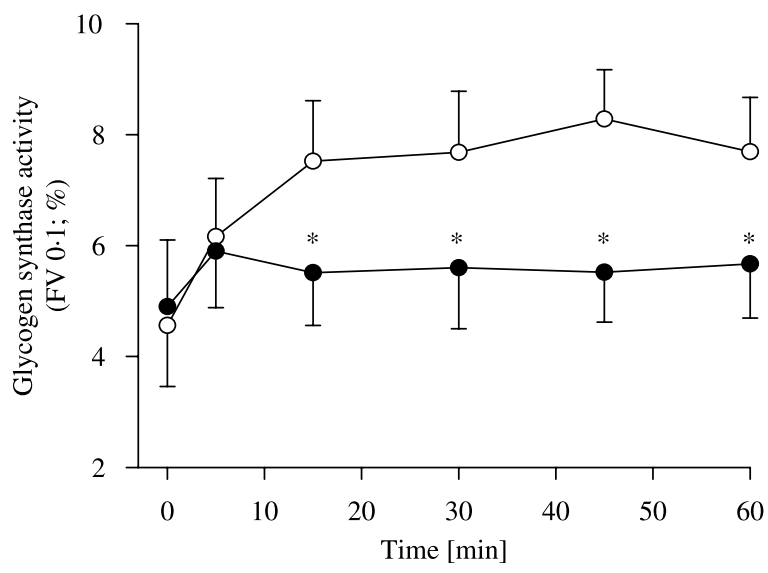

Figure 5 Effects of PD151746 on glycogen synthesis. HepG2 cells were incubated without $(O$ ) or with $(\bullet) 5.33 \mu \mathrm{mol} / \mathrm{I}$ PD151746 for $1 \mathrm{~h}$ and then stimulated with $100 \mathrm{nmol} / \mathrm{l}$ insulin for the indicated times. Cells were solubilized and reaction was started by adding a reaction mixture containing $25 \mathrm{mM} \mathrm{NaF}, 20 \mathrm{mM}$ EDTA, 1\% glycogen, $0 \cdot 7 \mu \mathrm{Ci} \mathrm{U}-\left[{ }^{14} \mathrm{C}\right]$ UDP glucose, $0 \cdot 3 \mathrm{mM}$ UDP glucose, and $0 \cdot 1 \mathrm{mM}$ G6P was added. Reaction was stopped after $15 \mathrm{~min}$ by precipitation of the total glycogen. Glycogen synthase activity was assayed in the presence of a near physiological concentration of $\mathrm{G} 6 \mathrm{P}(0 \cdot 1 \mathrm{mmol} / \mathrm{l})$ and in the presence of $10 \mathrm{mmol} / \mathrm{l} \mathrm{G} 6 \mathrm{P}$ to determine maximal enzyme activity. 

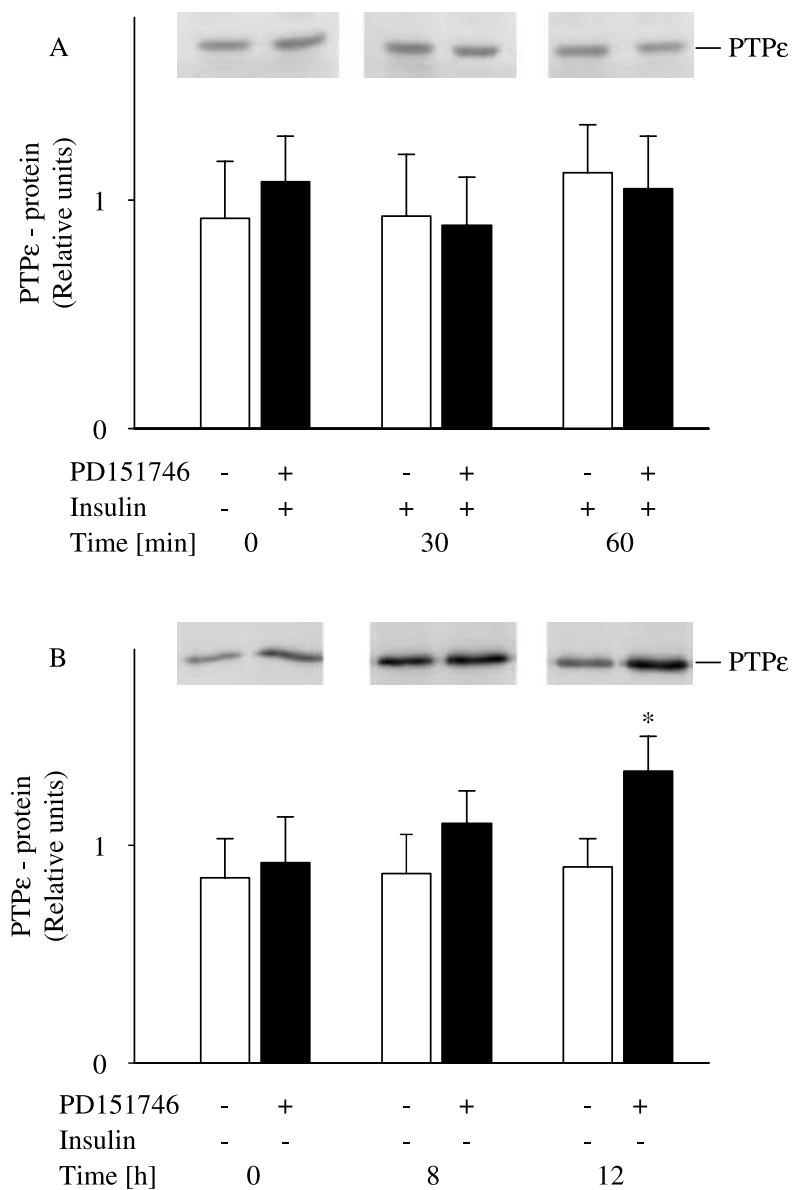

Figure 6 Effects of calpain on protein tyrosine phosphatase- $\varepsilon$ (PTPE). Cells were incubated without $(\square)$ or with $(\square) 5 \cdot 33 \mu \mathrm{mol} / \mathrm{l}$ PD151746 for 0, 30, or $60 \mathrm{~min}$ and then stimulated with $100 \mathrm{nmol} / \mathrm{I}$ insulin for the indicated times (A). In order to investigate long-term effects of calpain inhibition, cells were also incubated without $(\square)$ or with ( $5.33 \mu \mathrm{mol} / \mathrm{l}$ PD151746 for 0,8 , or $12 \mathrm{~h} \mathrm{(B).} \mathrm{PTP \varepsilon}$ protein amount was measured after solubilization of the cells by immunoblots with a specific anti-PTP $\varepsilon$ antibody. RUs were calculated as described. Shown are means \pm s.E.M. $(n=4)$. Insets show representative blots at the respective time points.

reduced GS activity within this time period. An incubation period of 8 or $12 \mathrm{~h}$, however, increased the PTPE protein amount. These data confirm the result of a study in human embryonic kidney HEK 293 cells suggesting that PTP $\varepsilon$ is cleaved by calpain (Gil-Henn et al. 2001). They also demonstrate that the calpain inhibitor PD151746 was effective in the HepG2 cells at all. Such a long-lasting calpain inhibitor effect on the PTP $\varepsilon$ protein amount may induce or enhance alterations of the GS activity and/or insulin signaling. However, since the PTPE protein amount was not altered after a calpain incubation period that clearly reduced the GS activity in HepG2 cells, the PTP $\varepsilon$ appears not to be involved. In any case, these data do not exclude a potential role of other phosphatases or a direct inhibition of the PTP $\varepsilon$ activity.

Another potential mechanism of a PI3-kinase-independent impairment of insulin-stimulated glycogen synthesis is the insulin-dependent pathway that mediates cytosolic actin reorganization. Actin filaments are an essential part of the cytoskeleton and are regulated by ubiquitous calpain isoforms (Mazeres et al. 2006). Actin filament formation facilitates insulin-stimulated GLUT4 translocation (Bose et al. 2002) and modulates the initiation of insulin-stimulated glycogen synthesis (Baque et al. 1997, Prats et al. 2005). Thus, disturbances of actin reorganization by inhibition of calpains might alter these insulin effects. This hypothesis is supported by a study by Paul et al. (2003), who observed that calpain inhibition reduced insulin-stimulated glucose uptake in 3T3 adipocytes. The authors showed that a reduction of insulinstimulated glucose uptake by calpain inhibition was not related with alterations of the insulin-stimulated PI3-kinase pathway but with a calpain-associated disruption of the insulin-mediated actin reorganization (Paul et al. 2003). Since actin cytoskeleton remodeling plays an important role in insulin-stimulated hepatic glycogen metabolism as well (Huang et al. 2002, Prats et al. 2005), calpain inhibition might, by this, also result in a PI3/Akt-kinase-independent impairment of glycogen synthesis in HepG2 cells.

It is also possible that calpains affect target proteins downstream of Akt. One such potential target proteins is the casein kinase 2 (CK2) that rapidly phosphorylates GS. This 'priming' phosphorylation is necessary to initiate further phosphorylation of GS by GSK-3 (Patel et al. 2004). Since CK2 is cleaved by CAPN2 (Roig et al. 1999), inhibition of calpains might increase GS 'priming' phosphorylation by CK2 and, consequently, enhance GS phosphorylation by GSK-3 resulting in inhibition of GS activity.

Finally, our data suggest that CAPN1 and CAPN2 are involved in the regulation of insulin-stimulated glycogen synthesis in human liver cells independently of the PI3kinase/Akt signaling pathway. Such an inhibition of calpain activity resulting in impaired hepatic glycogen synthesis might represent a potential mechanism that could contribute to the hepatic insulin resistance in type 2 diabetes.

\section{Funding}

The authors declare that there is no conflict of interest that would prejudice the impartiality of this scientific work.

\section{References}

Andersen JN, Elson A, Lammers R, Romer J, Clausen JT, Moller KB \& Moller NP 2001 Comparative study of protein tyrosine phosphataseepsilon isoforms: membrane localization confers specificity in cellular signalling. Biochemical Journal 354 581-590. 
Baier LJ, Permana PA, Yang X, Pratley RE, Hanson RL, Shen GQ, Mott D, Knowler WC, Cox NJ, Horikawa Y et al. 2000 A calpain-10 gene polymorphism is associated with reduced muscle mRNA levels and insulin resistance. Journal of Clinical Investigation 106 R69-R73.

Baque S, Guinovart JJ \& Ferrer JC 1997 Glyogenin, the primer of glycogen synthesis, binds to actin 1997. FEBS Letters 417 355-359.

Bose A, Guilherme A, Robida SI, Nicolori SM, Zhou QL, Jiang ZY, Pormerleau DP \& Czech MP 2002 Glucose transporter recycling in response to insulin is facilitated by myosin Myo1c. Nature 420 821-824.

Cox NJ, Hayes MG, Roe CA, Tsuchiya T \& Bell GI 2004 Linkage of Calpain 10 to type 2 diabetes. The biological rationale. Diabetes 53 (Suppl 1) S19-S25.

Gil-Henn H, Volohonsky G \& Elson A 2001 Regulation of protein-tyrosine phosphatases $\alpha$ and $\varepsilon$ by calpain-mediated proteolytic cleavage. Journal of Biological Chemistry 276 31772-31779.

Goll DE, Thompson VE, Li H, Wei W \& Cong J 2003 The calpain system. Physiological Reviews 83 731-801.

Hofmann C, Marsh JW, Miller B \& Steiner DF 1980 Cultured hepatoma cells as a model system for studying insulin processing and biologic responsiveness. Diabetes 29 865-874.

Horikawa Y, Oda N, Cox NJ, Li X, Orho-Melander M, Hara M, Hinokio Y, Lindner TH, Mashima H, Schwarz PE et al. 2000 Genetic variation in the gene encoding calpain-10 is associated with type-2 diabetes mellitus. Nature Genetics 26 163-175.

Huang D, Cheung AT, Parsons JT \& Bryer-Ash M 2002 Focal adhesion kinase (FAK) regulates insulin-stimulated glycogen synthesis in hepatocytes. Journal of Biological Chemistry 277 18151-18160.

Klein HH, Kowalewski B, Drenckhan M, Neugebauer S, Matthaei S \& Kotzke G 1993 A microtiter well assay system to measure insulin activation of insulin receptor kinase in intact human mononuclear cells. Diabetes $\mathbf{4 2}$ 883-890.

Klein HH, Vestergaard H, Kotzke G \& Pedersen O 1995 Elevation of serum insulin concentration during euglycemic hyperinsulinemic clamp studies leads to similar activation of insulin receptor kinase in skeletal muscle of subjects with or without NIDDM. Diabetes 44 1310-1317.

Kolter T, Uphues I \& Eckel J 1997 Molecular analysis of insulin resistance in isolated ventricular cardiomyocytes of obese Zucker rats. American Journal of Physiology Endocrinology and Metabolism 273 E59-E67.

Lynn S, Evans JC, White C, Frayling TM, Hattersley AT, Turnbull DM, Horikawa Y, Cox NJ, Bell GI \& Walker M 2002 Variation in the calpain-10 gene affects blood glucose levels in the British population. Diabetes 51 247-250.

Malecki MT, Moczulski DK, Klupa T, Wanic K, Cyganek K, Frey J \& Sieradzki J 2002 Homozygous combination of calpain 10 gene haplotypes is associated with type 2 diabetes mellitus in a Polish population. European Journal of Endocrinology 146 695-699.

Mazeres G, Leloup L, Daury L, Cottin P \& Brustis JJ 2006 Myoblast attachment and spreading are regulated by different patterns by ubiquitous calapains. Cell Motility and the Cytoskeleton 63 193-207.

Meyer MM, Levin K, Grimmsmann T, Beck-Nielsen H \& Klein H 2002 Insulin signalling in skeletal muscle of subjects with or without type II-diabetes and first degree relatives of patients with the disease. Diabetologia 45 813-822.

Nakagawa Y, Aoki N, Aoyama K, Shimizu H, Shimano H, Yamada N \& Miyazaki H 2005 Receptor-type protein tyrosine phosphatase epsilon (PTPepsilonM) is a negative regulator of insulin signaling in primary hepatocytes and liver. Zoological Science 22 169-175.
Otani K, Polonsky KS, Holloszy JO \& Han DH 2006 Inhibition of calpain results in impaired contraction-stimulated GLUT4 translocation in skeletal muscle. American Journal of Physiology, Endocrinology and Metabolism 16 (Epub ahead of print).

Parnaud G, Hammar E, Rouiller DG \& Bosco D 2005 Inhibition of Calpain blocks pancreatic $\beta$-cell spreading and insulin secretion. American Journal of Physiology, Endocrinology and Metabolism 289 E544-E548.

Patel S, Doble B \& Woodgett JR 2004 Glycogen synthase kinase-3 in insulin and Wnt signalling: a double-edged sword? Biochemical Society Transaction 32 803-808.

Paul DS, Harmon AW, Winston CP \& Patel YM 2003 Calpain facilitates GLUT4 vesicle translocation during insulin-stimulated glucose uptake in adipocytes. Biochemical Journal 376 625-632.

Pirola L, Johnston AM \& Van Obberghen E 2004 Modulation of insulin action. Diabetologia 47 170-184.

Prats C, Cadefau JA, Cusso R, Qvortrup K, Nielsen JN, Wojtaszewski JF, Hardie DG, Stewart G, Hansen BF \& Ploug T 2005 Phosphorylationdependent translocation of glycogen synthase to a novel structure during glycogen resynthesis. Journal of Biological Chemistry $\mathbf{2 8 0}$ 23165-23172.

Qiu W, Avramoglu RK, Dube N, Chong TM, Naples M, Au C, Sidiropoulos KG, Lewis GF, Cohn JS, Tremblay ML et al. 2004 Hepatic PTP-1B expression regulates the assembly and secretion of apolipoprotein B-containing lipoproteins: evidence from protein tyrosine phosphatase-1B overexpression, knockout, and RNAi studies. Diabetes $\mathbf{5 3}$ 3057-3066.

Raser KJ, Posner A \& Wang KK 1995 Casein zymography: a method to study $\mathrm{m}$-calpain, and their inhibitory agents. Archives of Biochemistry and Biophysics 319 211-216.

Roig J, Krehan A, Colomer D, Pyerin W, Itarte E \& Plana M 1999 Multiple forms of protein kinase CK2 present in leukemic cells: in vitro study of its origin by proteolysis. Molecular and Cellular Biochemistry 191 229-234.

Schütt M, Meier M, Meyer M, Klein J, Aries SP \& Klein HH 2000 The HIV-1 protease inhibitor indinavir impairs insulin signaling in HepG2 hepatoma cells. Diabetologia 43 1145-1148.

Sreenan SK, Zhou YP, Otani K, Hansen PA, Currie KP, Pan CY, Lee JP, Ostrega DM, Pugh W, Horikawa Y et al. 2001 Calpains play a role in insulin secretion an action. Diabetes 50 2013-2020.

Vaag A, Henriksen JE \& Beck-Nielson H 1992 Decreased insulin activation of glycogen synthase in skeletal muscles in young nonobese caucasian firstdegree relatives of patients with non-insulin-dependent diabetes mellitus. Journal of Clinical Investigation 89 782-788.

Yang X, Pratley RE, Baier LJ, Horikawa Y, Bell GI, Bogardus C \& Permana PA 2001 Reduced skeletal muscle calpain-10 transcript level is due to a cumulative decrease in major isoforms. Molecular Genetics and Metabolism $\mathbf{7 3}$ 111-113.

Received in final form 29 January 2007

Accepted 31 January 2007

Made available online as an Accepted Preprint 2 February 2007 